Bangladesh J. Sci. Ind. Res. 42(4), 441-448., 2007

\title{
Response of Late Sowing on the Yield and Yield Contributing Character of Different Varieties of Mustard and Rapeseed in Coastal Area of Barguna
}

\author{
M. A. Razzaque, M. Talukder, Shaleh Uddin, \\ S. I. Khan and Altab Hossain \\ Regional Agricultural Research Station, Bangladesh Agricultural Research Institute, \\ Rahmatpur, Barisal, Bangladesh
}

\begin{abstract}
An experiment was carried at Multi Location Testing site Barguna to determine suitable variety of mustard (Brassica species.) for the late sowing condition for the coastal area of Bangladesh during rabi season of 1998-1999 and 1999-2000. Four varieties of mustard such as Daulat, Rai-5, Improved tory-7, and Ishurdi local with four sowing dates viz.15 Nov, 23 Nov, 30 Nov. and 7 Dec. were used for the experiment. The experiment was laid out in a split plot design with sowing date in the main plot and varieties in the sub plot. The results revealed that the variety Daulat (1035 $\mathrm{kg} / \mathrm{ha}$ ) and Ishurdi local (1014 kg/ha) produced identically superior yield irrespective of sowing time. 15 November (1164 kg/ha) and 23 November (1002 kg/ha) recorded identically superior yield irrespect of variety. Daulat and Ishurdi local variety sowing could be delayed up to 30 November to obtain a profitable yield of (872 $\mathrm{kg} / \mathrm{ha})$ and (940 kg/ha) respectively which was still economically profitable.
\end{abstract}

Key words : Mustard and rapes, Late sowing, Variety, Yield, Coastal area.

\section{Introduction}

Rapes and Mustard (Brassica sp.) ranks first among the oilseed crops of Bangladesh. It covers about $61.2 \%$ of the total acarage under oil seed and $52.6 \%$ of the total oil seed production. Both acarage and production of the crop have been decreasing since the start of 1990-decade maturity due to ingression of cereal crops. As a result the country is facing huge cumulative shortage in edible oil and this deficiency costs a huge amount of foreign currency for import oils and oilseed every year. These crop have been vernalization requirement. Mendhan and Scott (1975) reported that plants from later sowing more rapidly fulfil the low temperature needs to initiate earlier inflorescence and flowering. But early initiation restricts leaf production resulting in small plants, fewer pod bearing 
branches and finally lower dry matter accumulation and lower yield. As the level of dry matter in plants decides the yield potential, seed yield from the late sown crops are greatly affected. Planting time plays a vital role in a country like Bangladesh, where climatic conditions vary throughout the country. Time of sowing determine the time of flowering and also it has great influence on dry matter accumulation, siliqua formation seed set, seed yield and seed oil content (Scott, et. al, 1973; Ali et. al, 1985 and Uddin et. al, 1986). Hossain et al (1984) and Uddin et al. (1986) concluded that the mid October was the most suitable time of sowing of rapeseed and mustard in Bangladesh (Uddin et. al, 1986 and Hossain et. al, 1984. One of the main reason for low yield of mustard in Banglsdesh is delay sowing of seeds due to delay in recession of flood water and late monsoon rain especially in the low land areas (Sarker and Paul, 1993). Bangladesh Agricultural research Institute (BARI) has developed and recommended a few high yield potential as well as late sown varieties of rape and mustard (Anonymous, 2001). These varieties may differ in their response to sowing dates for yield and yield components. Non saline phase of the Ganges tidal flood plain of southern region of Bangladesh comprise part of Barisal, Patuakhali, and Barguna districts characterized by tidal flooding of field, high rainfall in monsoon and short winter. Rice is the main crops grown in the kharif season. During the rabi season, land mainly remain fallow. Reason for fallow in the winter season delay of harvest of transplanted aman rice and wetness of soil. Land becomes free and soils comes to working condition at the end of the November to first week of January which is the time not optimum for sowing of many rabi crops due to most of the land cultivated under local T. aman and this aman rice harvest up to 1st week of January. Therefore, the present study was undertaken to find out a suitable variety of mustard and rapes for late sowing condition in coastal area of Bangladesh.

\section{Materials and Methods}

The experiment was carried out at Multilocation testing site Barguna of Bangladesh Agricultural Research Institute during rabi season of 1998-1999 and 19992000 under rainfed condition of coastal area. The soil of the experimental field was silty clay loam of Nalchity series containing sand $40 \%$, clay $30 \%$ and $30 \%$ sand having $\mathrm{pH}$ 6.24 and organic matter content $1.03 \%$. The experiment was laid out in split plot design with 4 replications assigned sowing date of main plot such as 15 November, 23 November, 30 November and 7 December and cultivars in sub plot viz. Daulat, Rai-5, Improved tory-7 and Ishurdi local. The unit plot size was $6 \mathrm{~m} \times 5 \mathrm{~m}$. The land was fertilized with NPKS @ 95-27-40-25 kg/ha in the form of urea, triple super phosphate, muriate and Gypsum at final land preparation because crop was cultivated in rainfed condi- 
tion. Seeds were sown in line. The distance between row-to-row $30 \mathrm{~cm}$ and seeds were sown continuously. One weeding and one thinning at 20-25 days after sowing were done to keep the crop weed free. The plants were sprayed with malathion for the control of aphid. Data were collected on plant height, branch per plant, siliqua per plant and seeds per siliqua recorded from 10 randomly selected plants from each plot. For seed yield estimation $3 \mathrm{~m} \times 3 \mathrm{~m}$ area from the middle was harvested. All the collected data were statistical analysis and means are adjudged LSD.

\section{Results and Discussions}

The area of Barguna sowing date and genotypes influenced the yield and yield attrib- utes of rapeseed and mustard, which was discussed under the heads as follows.

\section{Plant population $/ \mathbf{m}^{2}$}

Maximum plant population $/ \mathrm{m}^{2}$ (47.75) was obtained from sowing done on 15 November (Table I). But 23 November and 30 November gave plant population $/ \mathrm{m}^{2}$ which was statistically identical. Improved tory-7 gave the highest plant population $\left(53.50 / \mathrm{m}^{2}\right)$ followed by Daulat $\left(49.50 / \mathrm{m}^{2}\right)$. The lowest plants $/ \mathrm{m}^{2}$ (39.60) was obtained from 7 December sowing. It is also observed that late sowing reduced soil moisture which significantly reduced the germination percentage of rape seed and mustard.

Table I. Effect of sowing date and variety on plant population $/ \mathrm{m}^{2}$ and 1000 - seed weight (pooled)

\begin{tabular}{|c|c|c|c|c|c|c|c|c|c|c|}
\hline \multirow[t]{2}{*}{ Variety } & \multicolumn{5}{|c|}{$\begin{array}{l}\text { Siliqua/plant } \\
\text { Sowing date }\end{array}$} & \multicolumn{5}{|c|}{$\begin{array}{l}\text { Seed /siliqua } \\
\text { Sowing date }\end{array}$} \\
\hline & 15 Nov. & 23 Nov. & 30 Nov. & 7 Dec. & Mean & 15 Nov. & 23 Nov. & 30 Nov. & $7 \mathrm{Dec}$ & Mean \\
\hline Daulat & 49.50 & 46.50 & 49.25 & 43.5 & 47.19 & 2.05 & 2.0 & 1.92 & 1.94 & 1.98 \\
\hline Rai-5 & 43.50 & 43.25 & 44.25 & 39.6 & 42.63 & 1.72 & 1.74 & 1.67 & 1.64 & 1.69 \\
\hline Improved & 53.50 & 43.25 & 40.25 & 42.2 & 44.81 & 2.39 & 2.39 & 2.17 & 2.14 & 2.27 \\
\hline Tory-7 & & & & & & & & & & \\
\hline $\begin{array}{l}\text { Ishurdi } \\
\text { local }\end{array}$ & 44.50 & 41.75 & 41.75 & 40.70 & 42.19 & 2.51 & 2.45 & 2.45 & 2.45 & 2.46 \\
\hline Mean & 47.75 & 43.69 & 43.88 & 41.50 & & 2.17 & 2.14 & 2.05 & 2.04 & \\
\hline \multicolumn{3}{|c|}{ LSD (0.05) Variety } & 4.37 & $V(\%) 6$ & & \multicolumn{3}{|c|}{ LSD (0.05) Variety } & 0.061 & CV (\%) 4.1 \\
\hline \multicolumn{3}{|c|}{ Sowing date } & $6.00 \mathrm{C}$ & V (\%) 6 & & \multicolumn{3}{|c|}{ Sowing date } & 0.061 & CV(\%) 4.2 \\
\hline \multicolumn{3}{|c|}{ Sowing date $\mathrm{x}$ Variety } & 8.4 & & & \multicolumn{3}{|c|}{ Sowing date $\mathrm{x}$ Variety } & 0.123 & \\
\hline
\end{tabular}




\section{0 -seed weight}

Sowing date effects were less marked for seed weight except that the 7 December sowing which produced smaller seeds. Varietal characteristics were more pronounced regarding seed size. Larger seed produced by Ishurdi local (2.51 g/1000 seed) when sown on 15 November (Table I). Seed produced (1.64 g/1000 seed) by Rai-5 when sown on 7 December. This finding was agreed with Saran and Giri (1987). They reported that delayed sowing reduced 1000- seed weight and it ranged $11 \%$ compared to 25 October to 15 November.

\section{Plant height}

Sowing date linearly shortened the plant height and the different of this parameter between two successive dates were signifi- cantly (Table III). The highest plant height $(120 \mathrm{~cm})$ were obtained from 15 November sowing, which were reduced by $8 \%, 13.3 \%$ and $15 \%$ while seed were sown on 23 November, 30 November and 7 December respectively. Further, plant height significantly varied among the genotypes studied. Daulat produced the maximum plant height $(120 \mathrm{~cm})$, which was similar to Ishurdi local $(119 \mathrm{~cm})$. The shortest plants $(76.75) \mathrm{cm}$ height were obtained from Improved Tory -7 when it sown on 7 December.

\section{Siliquae/plant}

Sowing date had a great influence on the number of siliquae per plant, which may have apparent impact on seed yield. The highest number of siliquae/plant (119.35) (Table II) was attained in the first sowing

Table II. Effect of sowing date and variety on siliqua/plant and seed /siliqua (pooled)

\begin{tabular}{l|l|l|l|l|l|l|l|l|l|l|l}
\hline Variety & \multicolumn{5}{c|}{$\begin{array}{c}\text { Siliqua/plant } \\
\text { Sowing date }\end{array}$} \\
& 15 Nov. & 23 Nov. & 30 Nov. & 7 Dec. & Mean & 15 Nov. & 23 Nov. & 30 Nov. & 7 Dec & Mean \\
\hline & 119.35 & 110.0 & 78.58 & 78.0 & 96.48 & 12.10 & 11.85 & 11.65 & 9.70 & 11.32 \\
\hline Daulat & 116.0 & 86.32 & 74.20 & 81.0 & 89.38 & 11.00 & 11.00 & 10.65 & 9.30 & 10.49 \\
Rai-5 & 84.54 & 80.00 & 57.05 & 49.02 & 67.65 & 11.55 & 11.00 & 8.80 & 8.95 & 10.07 \\
Improved \\
Tory-7
\end{tabular}


date and thus significantly reduced thereafter. A serious reduction in siliqua/plant was noted with later sowing on 23 November, 30 November and 7 December and there were $11.54 \%, 27.79 \%$ and $32.84 \%$ lower than that of 15 November sowing. The reason for this lowering of siliquae/plant beyond 15 November sowing may be attributable to the fact that was probably fall in temperature had presumably switched plants to earlier initiation before they reached a critical size in terms of dry matter production (Scott et. $a l, 1973)$. Varietals differences for pod formation were also very large with Daulat yielding the highest number of pod than that of other varieties of 15 November sowing. Ishurdi local gave higher siliqua per plant than that of other cultivar at late sowing but it also gradually decreased. Among the sowing date and cultivars Improved tory-7 pro- duced minimum number of siliquae/plant (49.02) at last sowing date 7 December (Table II). This finding is agreement Nag et al. (2000). Rahman et al. (1993) reported that the number of siliquae/plant was greatly reduced for each week delayed after 2 November sowing (1993). Saran and Giri (1987) also obtained decreasing trends in pods $/ \mathrm{m}^{2}$ from sowing of weekly intervals on mid October to mid November.

\section{Seeds/siliqua}

The largest number of seeds per siliquae was obtained from 15 November sowing which was significantly at par than other sowing dates. Last sowing produced lowest number of seeds per siliquae (7 December) (Table II). Varieties were characteristically different in producing seed/siliqua. Daulat produced

Table III. Effect of sowing date and variety on seed yield and plant height (pooled)

\begin{tabular}{|c|c|c|c|c|c|c|c|c|c|c|}
\hline \multirow[t]{2}{*}{ Variety } & \multicolumn{5}{|c|}{$\begin{array}{c}\text { Seed yield (kg/ha) } \\
\text { Sowing date }\end{array}$} & \multicolumn{5}{|c|}{$\begin{array}{c}\text { Plant height }(\mathrm{cm}) \\
\text { Sowing date }\end{array}$} \\
\hline & 15 Nov. & 23 Nov. & 30 Nov. & 7 Dec. & Mean & 15 Nov. & 23 Nov. & 30 Nov. & 7 Dec. & Mean \\
\hline Daulat & 1360.00 & 1170.00 & 872.50 & 737.50 & 1035.00 & 120.00 & 119.00 & 104.5 & 102.25 & 111.44 \\
\hline Rai-5 & 977.00 & 725.00 & 552.50 & 467.50 & 680.63 & 115.00 & 113.25 & 111.75 & 111.50 & 112.87 \\
\hline $\begin{array}{l}\text { Improved } \\
\text { Tory-7 }\end{array}$ & 1162.00 & 1007.50 & 437.50 & 387.50 & 748.75 & 89.00 & 85.00 & 79.25 & 76.75 & 82.50 \\
\hline $\begin{array}{l}\text { Ishurdi } \\
\text { local }\end{array}$ & 115700 & 1105.00 & 940.00 & 855.00 & 1014.40 & 119.00 & 111.25 & 102.25 & 97.00 & 107.37 \\
\hline Mean & 1164.00 & 1001.90 & 700.63 & 611.90 & & 110.75 & 107.12 & 99.37 & 96.87 & \\
\hline \multicolumn{3}{|c|}{ LSD (0.05) Variety } & 209.28 & \%) 16.8 & \multicolumn{3}{|c|}{ LSD (0.05)Variety } & 7.12 & \multicolumn{2}{|c|}{ CV(\%) 9.6} \\
\hline \multicolumn{3}{|c|}{ Sowing date } & $212.82 \mathrm{C}$ & \%) 16.1 & \multicolumn{3}{|c|}{ Sowing date } & 4.24 & \multicolumn{2}{|c|}{ CV(\%) 0.013} \\
\hline \multicolumn{3}{|c|}{ Sowing date $\mathrm{x}$ variety } & 180.26 & & \multicolumn{3}{|c|}{ Sowing date $\mathrm{x}$ variety } & 0.32 & & \\
\hline
\end{tabular}


highest seed/siliqua (12.10) followed by Improved tory-7 and Ishurdi local. Similarly the variety-improved tory-7 gave the lowest number of seed/siliqua in 7 December sowing. The results of the present investigation with respect of seed/siliqua fairly agreed with the findings of Ghose and Chatterjee
(1998) who observed decreased seeds/siliqua in mustard and rapeseed due to later sowing. Islam and Sarker also observed higher number of seed/siliqua (12.86) from the early sowing (1-15 November) (1993).

Table IV. Economic performance of mustard and rapeseed

\begin{tabular}{l|r|r|r|r|r}
\hline Treatment & Yield (kg/ha) & $\begin{array}{c}\text { Gross return } \\
\text { (Tk/ha) }\end{array}$ & TVC(Tk/ha) & $\begin{array}{r}\text { Gross margin } \\
\text { (Tk/ha) }\end{array}$ & BCR \\
\hline T1V1 & 1360.00 & 27200 & 14199 & 13001 & 1.92 \\
T1V2 & 977.50 & 19550 & 14199 & 5351 & 1.38 \\
T1V3 & 1162.50 & 23250 & 14199 & 9051 & 1.64 \\
T1V4 & 1157.50 & 23150 & 14199 & 8951 & 1.63 \\
T2V1 & 1170.00 & 23400 & 14199 & 9201 & 1.65 \\
T2V2 & 725.00 & 14500 & 14199 & 301 & 1.02 \\
T2V32 & 1007.50 & 20150 & 14199 & 5951 & 1.42 \\
T2V4 & 1105.00 & 22100 & 14199 & 7901 & 1.56 \\
T3V1 & 872.50 & 17450 & 14199 & 3251 & 1.23 \\
T3V2 & 552.50 & 11050 & 14199 & -3149 & - \\
T3V3 & 437.50 & 8750 & 14199 & -5449 & - \\
T3V4 & 940.00 & 18800 & 14199 & 4601 & 1.32 \\
T4V1 & 737.50 & 14750 & 14199 & 551 & 1.03 \\
T4V2 & 467.50 & 9350 & 14199 & -4849 & - \\
T4V3 & 387.50 & 7750 & 14199 & -6449 & - \\
T4V4 & 855.00 & 17150 & 14199 & 2901 & 1.20 \\
\hline
\end{tabular}

T1=15 Nov. ,T2 = 23 Nov. ,T3 = Nov. ,T4 = Nov., V1= Daulat,, V2 = Rai-5, V3 = Improved Tory-7, V4= Ishurdi local, TVC $=$ Total variable cost, $\mathrm{BCR}=$ Benefit cost ratio

$\begin{array}{lrcr}\text { Input } & \mathrm{kg} / \mathrm{Tk} & \text { Output } & \mathrm{Tk} / \mathrm{kg} \\ \text { Seed } & 40.00 & \text { Mustard } & 20.00 \\ \text { Urea } & 7.00 & & \\ \text { TSP } & 15.00 & & \\ \text { MP } & 10.00 & & \\ \text { Gypsum } & 8.00 & & \end{array}$




\section{Seed yield}

Seed yield in rapeseed and mustard is a function number of siliqua per plant, number of seeds per siliqua and seed size. Sowing seeds on 15 November produced higher seed yield $(1360.00 \mathrm{~kg} / \mathrm{ha})$ than other sowing dates. Later sowing significantly reduced yield by $13.93 \%, 39.81 \%$ and $56.02 \%$ respectively 23 November, 30 November and 7 December sowing compared to 15 November sowing. Among the varieties Daulat gave highest seed yield (1364 kg/ha) in 15 November sowing and Improved Tory7 produced lowest yield (387.50kg/ha) in 7 December sowing (Table III). In 30 November Ishurdi local gave highest yield (940 kg/ha) comparable to Daulat (872.5 $\mathrm{kg} / \mathrm{ha}$ ). Delayed sowing reduced seed yield. These findings agreed with Rahman et al (1993). They observed that seed yield of rapeseed and mustard was gradually and significantly declined as sowing was delayed after 2 November. Bhagat and Singh concluded that seed yield of mustard reduction was a major function of sowing date and it was more or less uniform over all the varieties (Bhagat and Shingh, 1989). However Daulat and Ishurdi local gave higher yield at late sowing condition up to 30 November.

\section{Cost and Return Analysis}

The highest gross margin (13001 Tk/ha) and benefit cost ratio (1.92) were obtained from variety Daulat at 15 November sowing. These were followed by Ishurdi local at the same date of sowing. Gross margin gradually decreased for all subsequent sowing for all the varieties (Table IV).

\section{Conclusion}

From the above result it may be concluded that Daulat and Ishurdi local variety/genotype considered as late sowing (up to 30 November) in coastal area under the climatic condition of Bangladesh.

\section{References}

Ali, N. Shah S. A. H. and Rashid. A. (1985) Effect of sowing date on seed yield and yield components of Porbi Raya. Pakistan Journal of Agricultural Research. 6: 97100.

Anonymous, (2001). Annual Report, 1996-97, Bangladesh Agricultural Research Institute. pp-56-58.

BBS, (1995). Bangladesh Bureau of Statistics. Statistical year book of Bangladesh. Government of Bangladesh, Dhaka. p. 78.

Bhagat D.V. and S. Singh. (1989) Effect of date of sowing and varieties on seed quality, yield and aphid infestation of mustard. Bhartiya Krishi Anusandhana Patraic. 4 (4):179-183.

Ghosh, R.K. and Chatterajee. B.N (1998) Effect 
of dates of sowing on iolcontent and fatty acid profiles of Indian mustard. Indian $J$. Oilseed Res. 5 (2): 144 -149.

Hossain, M. Arbinda A.S. and Abedin. M. J. (1984) Effects of seed rate and time of sowing on the yield of mustard under rainfed condition. Bangladesh J. Agril. Rse. 9(1): 54-57.

Islam M. B. and Sarker. M.A.Z. Effects of different levels of boron on the yield of mustard. Research Report 1992-1993. BARI, Rangpur station pp. 1993:1-4.

Mendhan, N. J. and Scott. R. K. (1975) The limiting effect of plant size at inflorescence initiation on suvsequent growth and yield of oilseed rape (Brassica napus L.) Agric. Sci. Camb. 84: 487-502.

Nag B.L. Karim, M. Islam N. and Quddus. M. A. (2000) Effect of sowing time on the yield and yield attributes of selected mustard and rapeseed genotypes in saline area of kalapara. Progress. Agric. 11(1\&2) :4550 .

Rahman, M. M., Hossain, M.A.S. Islam., N Jahiruddin M. and Salam. M. U. (1993) Effect of sowing date and boron fertilizer on the yield and oil content of mustard and rapeseed. Bangladesh Agron. Journal. 5(1\&2): $73-78$.
Saran and G. Giri. (1987) Influence of dates of sowing on Brassica species under semi arid rainfed conditions of north west India. Journal of Agricultural Science (Camb). 108 : 561-566.

Sarker M. A. and Paul N.K (1993) Physiological analysis of delayed sowing on yield of rapeseed (Brassica campestries L.) Bangladesh J. Agril. Res. 18 : 25-33.

Scott, R. K. Ogungemi, E. A. Lvins J. D. and Mendham. N. J. (1973) The effect of sowing dates and season on growth and yield of oilseed rape (Brassica napus). Journal of Agricultural Science (Camb). 81 : 277285.

Uddin, M.M. Samad, A. Khan, M.R. Begum S. and Salam. M.A. (1986) Effects of sowing dates on the yield and some of its components of mustard and rapeseed. Bangladesh J. Sci. Ind. Res. 21 (2): 160165.

Received : July 15, 2007;

Accepted : September 12, 2007 